\title{
Penentuan Prioritas Ruang Terbuka Hijau berdasarkan Efek Urban Heat Island di Wilayah Surabaya Timur
}

\author{
Nabiilatul Arifah dan Cahyono Susetyo \\ Perencanaan Wilayah dan Kota, Fakultas Arsitektur Desain dan Perencanaan, \\ Institut Teknologi Sepuluh Nopember (ITS) \\ e-mail: cahyono_s@urplan.its.ac.id
}

\begin{abstract}
Abstrak-Urban Heat Island menjadi fenomena yang mengaitkan antara kenaikan suhu permukaan dengan aktivitas manusia, yaitu pembangunan. Wilayah Surabaya Timur mengalami perkembangan pembangunan yang pesat dalam 10 tahun terakhir. Proyek infrastruktur MERR dan rencana JLLT yang ditargetkan selesai pada 2019 meningkatkan potensi konversi lahan non terbangun menjadi kawasan hunian, komersial, dan sebagainya. Wilayah Surabaya Timur mengalami kenaikan suhu maksimal dari $33,7^{\circ} \mathrm{C}$ menjadi $34^{\circ} \mathrm{C}$ dalam rentang waktu 2013-2016. Pemerintah Kota Surabaya berupaya untuk menyeimbangkan lingkungan dengan penyediaan Ruang Terbuka Hijau (RTH) agar dapat menurunkan suhu. Oleh karena itu diperlukan adanya penentuan penambahan RTH yang memperhatikan aspek fisik, biologis, dan sosial dilihat dari indeks kenyamanan, kerapatan vegetasi, dan kepadatan penduduk. Tujuan dari penelitian ini adalah menentukan prioritas RTH sebagai penambahan luasan dari RTH eksisting di Wilayah Surabaya Timur yang dicapai melalui tahapan penelitian sebagai berikut : (1) Mengidentifikasi faktor-faktor penentuan prioritas RTH di Wilayah Surabaya Timur; (2) Menentukan prioritas RTH di Wilayah Surabaya Timur. Hasil penelitian ini menunjukkan bahwa penentuan prioritas RTH didasarkan pada overlay antara aspek biologis kerapatan vegetasi dari nilai NDVI, aspek fisik dari indeks kenyamanan THI, dan kepadatan penduduk. Prioritas RTH terdiri dari RTH eksisting dan rekomendasi penambahan RTH dilihat dari overlay skor 4 (moderate priority) dan skor 5 (high priority) di lahan non terbangun. Hasil penentuan prioritas RTH menunjukkan penambahan RTH dari RTH eksisting dilakukan pada 663,23 Ha tambak, 2,14 Ha tanah kosong, dan 129,30 Ha lahan pertanian. Arahan penambahan RTH dari prioritas RTH meningkatkan luasan RTH eksisting 783,06 Ha menjadi 1.577,73 Ha atau 16,18\% dari total Wilayah Surabaya Timur.
\end{abstract}

Kata Kunci- Overlay, RTH, Remote Sensing, Urban Heat Island.

\section{PENDAHULUAN}

$\mathrm{T}$ INGGINYA laju urbanisasi ditandai dengan meningkatnya lahan terbangun terutama permukiman dan industri menjadi salah satu penyebab meluasnya fenomena yang disebut dengan Urban Heat Island[1]. Urban Heat Island ditandai dengan terjadinya kenaikan suhu atmosfer dan permukaan yang terjadi di area perkotaan dibandingkan daerah pedesaan dan sekitarnya. Jenis tutupan vegetasi mampu menetralkan peningkatan suhu permukaan karena vegetasi melakukan evaporasi dan transpirasi yang mampu melepaskan air ke udara sehingga dapat mengurangi temperatur udara di sekitarnya[2].

Kota Surabaya menjadi salah satu kota besar yang memiliki jumlah penduduk tertinggi kedua di Indonesia setelah Jakarta Timur[3]. Dengan jumlah penduduk sebesar
3.016.653 jiwa dan kepadatan penduduk sebesar 9.231 jiwa/ $\mathrm{km}^{2}$ pada tahun 2016 Kota Surabaya termasuk dalam klasifikasi Kota Metropolitan. Kondisi ini menunjukkan bahwa Kota Surabaya memiliki aktivitas yang semakin padat. Hal ini didukung dengan peningkatan pertumbuhan penduduk dari tahun 1990-2000 menunjukkan angka 0,5\%, menjadi 0,63\% pada tahun 2000-2010[4].

Dengan perkembangan lahan yang semakin padat di Kawasan Surabaya Timur berimplikasi pada berkurangnya lahan vegetasi seperti RTH, Tambak, dan Hutan Mangrove. Penyusutan alokasi area untuk RTH mengakibatkan tingkat penyerapan karbon semakin kecil dan berdampak pada peningkatan suhu permukaan tanah[5]. Data temperatur yang diukur stasiun Juanda Surabaya menunjukkan peningkatan suhu rata-rata dalam satu tahun. Suhu maksimum tahun 2013 sebesar $33,7^{\circ} \mathrm{C}$ mengalami peningkatan menjadi $34,0^{\circ} \mathrm{C}$ pada tahun 2016. Sedangkan suhu minimum juga meningkat dari 22, $6^{\circ} \mathrm{C}$ pada tahun 2013 menjadi $23,4^{0} \mathrm{C}$ pada tahun 2016[4].

Tingginya peluang perubahan penggunaan lahan di Surabaya Timur mengakibatkan kebutuhan akan ruang terbuka hijau yang mampu menurunkan suhu permukaan semakin tinggi. Metode penyediaan RTH di Indonesia pada umumnya hanya mengukur luasan yang diperlukan, tidak diketahui lokasi yang harus dikembangkan agar berfungsi secara optimal dalam menurunkan suhu udara perkotaan. Metode penentuan prioritas RTH yang cepat dan akurat diperlukan dengan representasi spasial berdasarkan karakteristik biologi, fisik, sosial, dan ekonomi wilayah[6]. Aspek fisik dan biologi dari wilayah kota-kota besar di Asia digunakan untuk menentukan hubungan antara fenomena Urban Heat Island dengan karakteristik tutupan lahan dengan melakukan tumpang tindih (overlay) peta penutupan lahan, kerapatan vegetasi (NDVI), dan suhu permukaan[7]. Metode penentuan prioritas pembangunan infrastruktur RTH dapat dilakukan dengan menggunakan nilai suhu permukaan, data kependudukan, dan letak fasilitas publik dimana lokasi prioritas RTH sebagai lokasi dengan suhu permukaan yang lebih tinggi, padat penduduk, dengan aktivitas publik yang tinggi[8].

Penelitian ini bertujuan untuk menentukan penambahan RTH di kawasan yang belum terbangun dengan kriteria ditentukan pada aspek fisik, biologis, dan sosial dilihat dari indeks kenyamanan, kerapatan vegetasi, dan kepadatan penduduk. Sehingga pada akhirnya prioritas RTH hasil analisa mampu menurunkan efek dari fenomena Urban Heat Island. 


\section{METODE PENELITIAN}

\section{A. Pendekatan dan Jenis Penelitian}

Pendekatan yang digunakan dalam penelitian ini adalah pendekatan positivistik yang memandang fenomena itu dapat diklasifikasikan, relatif tetap, konkrit, teramati, terukur, dan hubungan gejala bersifat sebab akibat[9]. Sedangkan jenis penelitian yang digunakan adalah deskriptif dan kuantitatif.

\section{B. Variabel Penelitian}

Variabel yang digunakan untuk menentukan prioritas Ruang Terbuka Hijau di Wilayah Surabaya Timur disebut sebagai faktor penentuan prioritas RTH dibagi dalam 3 aspek. Aspek biologis ditentukan oleh variabel kerapatan vegetasi NDVI (Normalized Difference Vegetation Index). Aspek Fisik dilihat dari variabel nilai indeks kenyamanan THI (Temperature Humidity Index) yang diperoleh dari variabel suhu permukaan LST (Land Surface Temperature) dan variabel kelembaban relatif RH (Reltaive Humidity). Aspek Sosial dilihat dari kepadatan penduduk di tiap kelurahan di Wilayah Surabaya Timur.

\section{Metode Pengumpulan Data}

Teknik pengumpulan data dalam penelitian ini menggunakan teknik pengumpulan data sekunder dari instansi/badan/organisasi terkait. Berikut data digunakan dalam penelitian dan sumber data.

Tabel 1.

Teknik Pengumpulan Data Sekunder

\begin{tabular}{ccc}
\hline \hline No & Data & Sumber Data \\
\hline 1 & Citra Landsat 8 Band 4, 5, 10, dan 11 & Earth Explorer, NASA \\
2 & Kelembaban Relatif & BMKG Surabaya \\
3 & Kepadatan Penduduk & BPS Kota Surabaya \\
4 & Penggunaan Lahan Surabaya Timur & Bappeko Kota Surabaya \\
\hline \hline
\end{tabular}

D. Mengidentifikasi Faktor-Faktor Penentuan Prioritas Ruang Terbuka Hijau di Wilayah Surabaya Timur

Identifikasi faktor penentuan prioritas RTH dibagi dalam 3 aspek yang diidentifikasi yaitu kerapatan vegetasi, indeks kenyamanan, dan kepadatan penduduk.

Identifikasi kerapatan vegetasi dilakukan dengan citra Landsat 8 Band 4 (Red) dan Band 5 (NIR) yang sudah dilakukan koreksi reflectance. Berikut persamaan koreksi reflectance “(1)."

$$
\rho \lambda^{\prime}=M \rho * Q C a l+A \rho
$$

$\rho \lambda^{\prime}=$ ToA Planetary Spectral Reflectance, tanpa koreksi untuk solar angle

$M \rho=$ Reflectance multiplicative scaling factor for the band (REFLECTANCEW_MULTI_BAND_n from the metadata)

$A \rho=$ Reflectance additive scaling factor for the band (REFLECTANCE_ADD_BAND_n from the metadata)

Qcal = L1 pixel value in DN

Perhitungan NDVI dari band 4 (Red) dan band 5 (NIR) menggunakan formula “(2).”

$$
N D V I=\frac{(N I R-R e d)}{(N I R+R e d)}
$$

Nilai NDVI berkisar antara -1 sampai dengan 1. Nilai NDVI $<0$ atau yang bernilai negatif cenderung merupakan perairan bebas. Sehingga tidak memprioritaskan lokasi RTH pada indeks NDVI $\leq 0$ dan mengklasifikasikan kondisi kerapatan vegetasi pada indeks $>0$ dengan klasifikasi sebagai berikut[6].
Tabel 2.

Klasifikasi Tingkat Kerapatan Vegetasi dari Nilai NDVI[6]

\begin{tabular}{ccc}
\hline \hline No & Data & Sumber Data \\
\hline 1 & $\leq 20 \%$ & Sangat Jarang \\
2 & $21-40 \%$ & Jarang \\
3 & $41-60 \%$ & Sedang \\
4 & $61-80 \%$ & Padat \\
5 & $\geq 80 \%$ & Sangat Padat \\
\hline \hline
\end{tabular}

Aspek selanjutnya yaitu indeks kenyamanan didapatkan dari kalkulasi antara estimasi suhu permukaan dan kelembaban relatif. Metode yang digunakan untuk mendapatkan estimasi suhu permukaan digunakan olah citra satelit[10] dari Band Thermal pada Landsar 8 yaitu Band 10 dan Band 11.

Untuk mendapatkan sebaran suhu permukaan diperlukan koreksi radiance band thermal (Band 10 dan 11) dengan formula "(3)", dilanjutkan dengan konversi ke dalam Satellite Brightness Temperature “(4)”

$$
L \lambda=M l Q c a l+A l
$$

$\mathrm{L} \lambda=$ Spectral radiance $\left(\mathrm{W} /\left(\mathrm{m}^{2 *} \mathrm{sr} * \mu \mathrm{m}\right)\right)$

$\mathrm{Ml}=$ Radiance multiplicative scaling factor for the band (RADIANCE_MULTI_BAND_n from the metadata)

$\mathrm{Al} \quad=$ Radiance additive scaling factor for the band (RADIANCE_ADD_BAND_n from the metadata)

Qcal = L1 pixel value in DN

$T=\frac{K 2}{\ln \left(\left(\frac{K 1}{L \lambda}\right)+1\right)}-273,15$

$T=$ Temperature $\left({ }^{0} \mathrm{C}\right)$

K1 = Band-specific Thermal Convertion Constant from the metadata (K1_CONSTANT_BAND_X, Where $X$ is the band number, 10 or 11)

K2 = Band-specific Thermal Convertion Constant from the metadata (K2_CONSTANT_BAND_X, Where $X$ is the band number, 10 or 11$)$

$\mathrm{L} \lambda=$ Spectral radiance $\left(\mathrm{W} /\left(\mathrm{m}^{2 *} \mathrm{sr}^{*} \mu \mathrm{m}\right)\right)$

273,15 = Angka konversi Kelvin menjadi Celcius

Hasil perhitungan $T$ menghasilkan temperatur dari band 10 dan 11, dilakukan rata-rata dengan tools Cell Statistic dalam ArcGIS dengan pilihan overlay statistic mean. Kemudian menghitung nilai Deriving LSE (e) "(4)” dengan nilai Pv dari formula “(5)” yang menggunakan hasil perhitungan NDVI.

$$
\begin{aligned}
& e=0,004 P v+0,986 \\
& P v=\left(\frac{\text { NDVI }- \text { NDVImin }}{\text { NDVImax }- \text { NDVImin }}\right)^{2}
\end{aligned}
$$

Langkah terakhir dalam menentukan nilai LST yaitu menghitung nilai LST untuk masing-masing band (band 10 dan 11) dengan formula “(6)."

$$
\begin{aligned}
& \text { LST }=\frac{T}{1}+w *\left(\frac{T}{\rho}\right) * \ln (e) \\
T= & \text { Temperature }\left({ }^{0} \mathrm{C}\right) \\
W= & \text { Wavelength of emmited rediance }(10,8 \mu \mathrm{m} \rightarrow \text { band } \\
& 10 ; 12 \mu \mathrm{m} \rightarrow \text { band } 11) \\
\rho \quad & \mathrm{h} * \mathrm{c} / \mathrm{s}\left(1.438 * 10^{-2} \mathrm{mK}\right) \\
& \mathrm{h}=\text { Planck's constant }\left(6,626 * 10^{-34} \mathrm{Js}\right) \\
& \mathrm{c}=\text { velocity of light }\left(2,998 * 10^{8} \mathrm{~m} / \mathrm{s}\right) \\
& \mathrm{s}=\text { Boltzmann's constant }\left(1,38 * 10^{-23} \mathrm{~J} / \mathrm{K}\right) \\
\rho \quad & 14380 \\
\text { LST } & \text { kemudian di rata-rata dari Band } 10 \text { dan } 11
\end{aligned}
$$
menggunakan cell statistic sehingga dihasilkan peta sebaran suhu permukaan.

Sedangkan untuk mendapatkan sebaran kelembaban relatif (Relative Humidity) digunakan metode interpolasi IDW 
(Inverse Distance Weighted) yang mampu menspasialkan data sebaran dari data titik. Sampel yang digunakan adalah titik dari stasiun BMKG di sekitar wilayah studi yaitu Stasiun BMKG Perak I, Stasiun BMKG Perak II, dan Stasiun BMKG Juanda.

Kalkulasi indeks kenyamanan digunakan rumus Nieuwolt “(7).” Klasifikasi tingkat kenyamanan dibedakan menjadi tiga kelas yaitu kelas nyaman dengan nilai THI 21 - 24, kelas kurang nyaman dengan nilai THI antara 25 sampai 27, dan kelas tidak nyaman dengan selang nilai THI lebih dari 27 [6].

$$
\begin{aligned}
T H I= & (0,8 * T)+\left[\frac{R H * T}{500}\right] \\
T & =\text { Temperature }\left({ }^{0} \mathrm{C}\right) \\
R H & =\text { Relative Humidity }(\%)
\end{aligned}
$$

Aspek ketiga yang menjadi faktor penentuan prioritas RTH adalah aspek sosial dilihat dari kepadatan penduduk. Data kepadatan penduduk diperoleh dari data BPS Kota Surabaya untuk diidentifikasi kepadatan penduduk pada unit terkecil yaitu kelurahan. Penggunaan kepadatan penduduk sebagai faktor penentu prioritas RTH disebabkan karena fenomena Urban Heat Island cenderung ditemukan pada kawasan urban yang padat penduduk[6]. Teknik yang digunakan adalah input data dalam bentuk polygon yang dikonversi ke format raster dengan tools polygon to raster dalam ArcGIS. Berikut klasifikasi tingkat kepadatan penduduk[6].

Tabel 3.

Klasifikasi Kepadatan Penduduk[6]

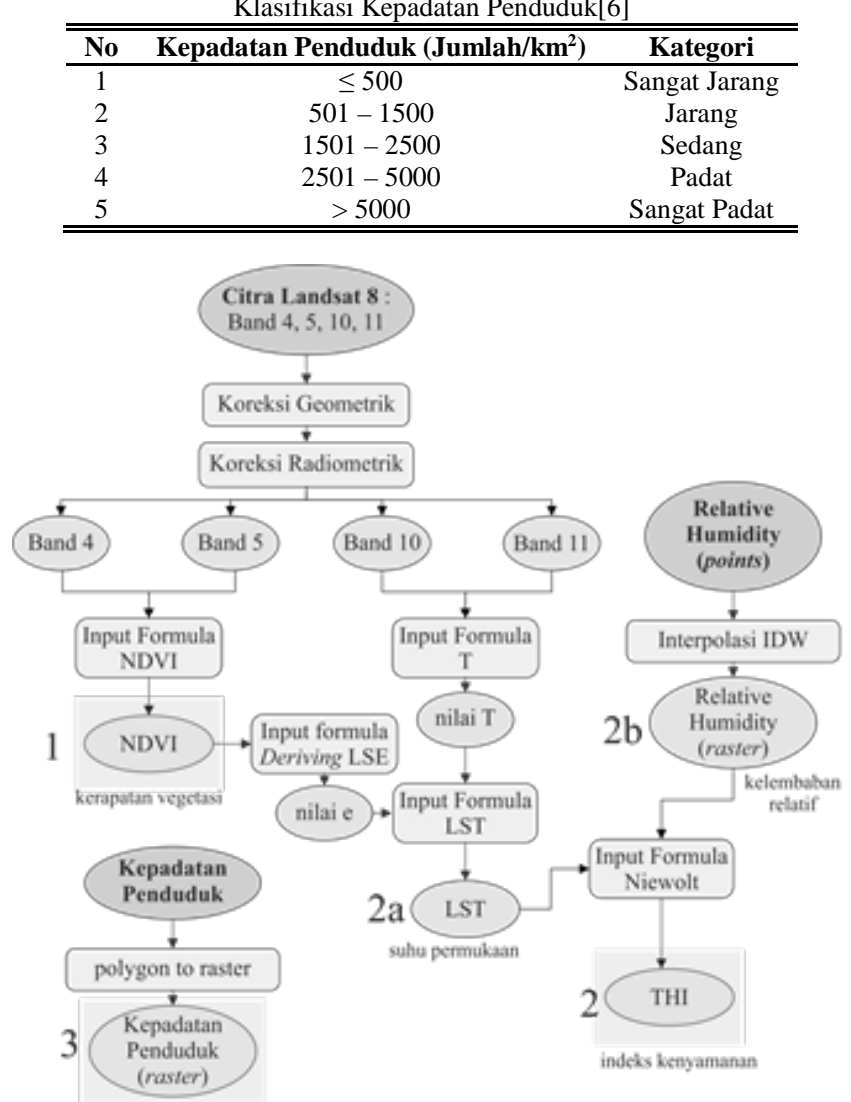

Gambar 1. Alur Kerja Identifikasi Faktor-Faktor Penentuan Prioritas Ruang Terbuka Hijau di Wilayah Surabaya Timur

\section{E. Menentukan Prioritas Ruang Terbuka Hijau di Wilayah Surabaya Timur}

Untuk menentukan prioritas Ruang Terbuka Hijau, analisa yang digunakan adalah teknik overlay untuk menyatukan beberapa obyek sehingga mempermudah proses analisa berdasarkan posisi spasial[6]. Analisa overlay dilakukan dengan menggunaan tools Weighted Overlay pada ArcGIS dengan meletakkan ketiga peta yang dianalisa (THI, NDVI, dan Kepadatan Penduduk) beserta atributnya.

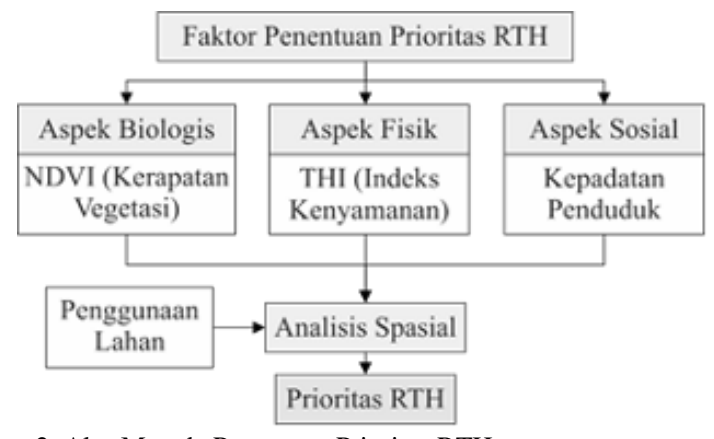

Gambar 2. Alur Metode Penentuan Prioritas RTH

Overlay dilakukan antara peta THI, Kerapatan Vegetasi (NDVI), dan Kepadatan Penduduk dengan kriteria skor. Wilayah yang memiliki skor terbanyak merupakan wilayah yang menjadi prioritas untuk pengembangan ruang terbuka hijau (RTH) dalam 2 prioritas (high priority dan moderate priority) di 2 kelas dengan skor tertinggi[6].

\begin{tabular}{|c|c|c|c|}
\hline No & Indikator & Kriteria & Skor \\
\hline \multirow{3}{*}{1} & \multirow{3}{*}{ THI } & $21-24$ & 1 \\
\hline & & $25-27$ & 3 \\
\hline & & $>27$ & 5 \\
\hline \multirow{5}{*}{2} & \multirow{5}{*}{ Kerapatan Vegetasi } & Sangat Jarang & 5 \\
\hline & & Jarang & 4 \\
\hline & & Sedang & 3 \\
\hline & & Rapat & 2 \\
\hline & & Sangat Rapat & 1 \\
\hline \multirow{5}{*}{3} & \multirow{5}{*}{$\begin{array}{c}\text { Kepadatan Penduduk } \\
\left.\text { (Jiwa/ } / \mathrm{Km}^{2}\right)\end{array}$} & Sangat Jarang $(\leq 500)$ & 1 \\
\hline & & Jarang $(501-1500)$ & 2 \\
\hline & & Sedang $(1501-2500)$ & 3 \\
\hline & & Padat $(2501-5000)$ & 4 \\
\hline & & Sangat Padat $(>5000)$ & 5 \\
\hline
\end{tabular}

Tabel 4.

Kriteria Penentuan Prioritas RTH[6]

Untuk mendapatkan arahan prioritas RTH, hasil lokasi prioritas RTH perlu diidentifikasi jenis penggunaan lahannya dengan tools intersect pada ArcGIS. Sehingga prioritas RTH pada lahan terbangun diarahkan untuk penghijauan kawasan, sedangkan prioritas RTH pada lahan non terbangun diarahkan untuk dikonversi menjadi RTH yang ekologis. Jenis penggunaan lahan RTH tetap akan menjadi Prioritas RTH tanpa mempertimbangkan skor dari hasil overlay.

\section{HASIL DAN PEMBAHASAN}

\section{A. Identifikasi Faktor-Faktor Penentuan Prioritas Ruang} Terbuka Hijau di Wilayah Surabaya Timur

Identifikasi faktor dibagi dalam 3 aspek. Aspek biologis yaitu kerapatan vegetasi dilihat dari NDVI dengan formula “(2)”. Hasil indeks vegetasi di Wilayah Surabaya Timur menunjukkan NDVI minimumnya adalah -0,6156 dan maksimumnya adalah 0,8029 dari skala indeks NDVI -1 sampai dengan 1.

Klasifikasi nilai indeks NDVI berdasarkan klasifikasi yang sudah ditetapkan dengan nilai indeks $\leq 0$ sebagai non vegetasi dan indeks $>0$ diklasifikasikan dengan tingkat kerapatan menghasilkan proporsi sebagai berikut.

Tabel 5.

Klasifikasi Kerapatan Vegetasi di Wilayah Surabaya Timur

\begin{tabular}{cccrc}
\hline \hline No & $\begin{array}{c}\text { Nilai Indeks } \\
\text { Vegetasi }\end{array}$ & Kerapatan & Luas (Ha) & $\begin{array}{c}\text { Prosentase } \\
(\%)\end{array}$ \\
\hline 1 & $\leq 0$ & Non Vegetasi & 518,13 & 5,32 \\
2 & $>0-0,16$ & Sangat Jarang & $2.869,11$ & 29,44 \\
3 & $>0,16-0,32$ & Jarang & $3.639,96$ & 37,35 \\
\hline \hline
\end{tabular}




\begin{tabular}{cccrc}
\hline \hline No & $\begin{array}{c}\text { Nilai Indeks } \\
\text { Vegetasi }\end{array}$ & Kerapatan & Luas (Ha) & $\begin{array}{c}\text { Prosentase } \\
\mathbf{( \% )}\end{array}$ \\
\hline 4 & $>0,32-0,48$ & Sedang & $1.732,14$ & 17,77 \\
5 & $>0,48-0,64$ & Padat & 770,67 & 7,91 \\
6 & $>0,64$ & Sangat Padat & 216,54 & 2,22 \\
Total Luas & & $9.746,55$ & 100 \\
\hline \hline
\end{tabular}

Wilayah Surabaya Timur dominan memiliki tingkat kerapatan vegetasi jarang dengan prosentase 37,35\% dari total wilayah. Sedangkan kondisi terendah dengan tingkat kerapatan vegetasi sangat padat yaitu 2,22\% dari total luas wilayah Surabaya Timur.

Berdasarkan nilai indeks vegetasi, arahan prioritas RTH berada pada area dengan kondisi kerapatan vegetasi sangat jarang yaitu 29,44\% wilayah penelitian sebagai prioritas tertinggi (high priority) dan area kerapatan vegetasi jarang yaitu $37,35 \%$ wilayah penelitian sebagai prioritas kedua (moderate priority).

Aspek fisik ditentukan dari indeks kenyamanan yang berasal dari kalkulasi antara suhu permukaan LST dan kelembaban relatif di Wilayah Surabaya Timur.

Hasil perhitungan suhu permukaan LST di Wilayah Surabaya Timur dengan menggunakan gabungan dari band thermal (band 10 dan band 11) yang dihasilkan rentang suhu di wilayah Surabaya Timur sebesar $23,7352^{\circ} \mathrm{C}$ hingga $36,4061^{\circ} \mathrm{C}$ dengan rata-rata $29,95^{\circ} \mathrm{C}$. Suhu tinggi menunjukkan di area barat dari wilayah Surabaya Timur tepatnya di area dengan kepadatan tinggi, sedangkan suhu rendah berada di area timur tepatnya di area yang masih belum terbangun, yaitu area tambak dan mangrove.

Nilai kelembaban relatif diperoleh dari titik pengukuran BMKG di Kota Surabaya. Kelembaban relatif dari stasiun Perak I 66,0\%, stasiun Perak II 74,5\%, dan stasiun Juanda $73,4 \%$ [4]. Data dari ketiga stasiun di atas digunakan untuk mengestimasi kelembaban relatif di wilayah studi dengan teknik interpolasi IDW (Inverse Distance Weighted) yang mampu menspasialkan data sebaran dari data titik.

Hasil interpolasi menunjukkan sebaran kelembaban relatif di Wilayah Surabaya Timur berkisar antara 69,465\% sampai dengan 73,1528\%. Kondisi ini lebih banyak dipengaruhi oleh kelembaban yang diukur dari stasiun juanda yang berbatasan dengan wilayah Surabaya Timur.

Dengan menggunakan input sebaran suhu permukaan dan estimasi kelembaban relatif di Wilayah Surabaya Timur dapat diketahui indeks kenyamanan dengan rumus Nieuwolt “(7).”

Kalkulasi indeks kenyamanan THI dengan rumus Nieuwolt menggunakan tools raster calculator dalam ArcGIS. Hasilnya menunjukkan tingkat kenyamanan di Wilayah Surabaya Timur antara THI 22,4045 hingga THI 34,3248 .

Tabel 6.

Klasifikasi Tingkat Kenyamanan THI di Wilayah Surabaya Timur

\begin{tabular}{cccrc}
\hline \hline No & Nilai THI & Keterangan & Luas (Ha) & Prosentase (\%) \\
\hline 1 & $\leq 24$ & Nyaman & 838,35 & 8,6 \\
2 & $>24-27$ & Kurang Nyaman & $1.666,80$ & 17,1 \\
3 & $>27$ & Tidak Nyaman & $7.241,40$ & 74,3 \\
\hline \multicolumn{2}{c}{ Total Luas } & $9.746,55$ & 100 \\
\hline \hline
\end{tabular}

Wilayah Surabaya Timur dominan pada tingkat kenyamanan tidak nyaman (THI > 27) dengan prosentase $74,30 \%$ dari total wilayah. Sedangkan kondisi kurang nyaman dengan THI antara 24 dan 27 sebesar 17,1\% dari total wilayah dan kondisi nyaman dengan $\mathrm{THI} \leq 24$ yaitu $8,6 \%$ dari total luas wilayah Surabaya Timur. Berdasarkan nilai THI, arahan prioritas RTH berada pada area dengan kondisi tidak nyaman (THI > 27) yaitu 74,3\% wilayah penelitian sebagai prioritas tertinggi (high priority).
Aspek sosial sebagai faktor penentu prioritas RTH ditunjukkan dengan tingkat kepadatan penduduk. Besar kepadatan penduduk diperoleh dari jumlah penduduk tiap luasan wilayah dengan klasifikasi sesuai dengan Tabel 3.

Tabel 7.

Klasifikasi Kepadatan Penduduk di Wilayah Surabaya Timur[4]

\begin{tabular}{|c|c|c|c|}
\hline No & Kelurahan & $\begin{array}{l}\text { Kepadatan } \\
\left(\mathrm{Jiwa} / \mathrm{Km}^{2}\right)\end{array}$ & Klasifikasi \\
\hline \multicolumn{4}{|c|}{ Kecamatan Tambaksari } \\
\hline 1 & Dukuh Setro & $19.225,89$ & Sangat Padat \\
\hline 2 & Pacar Keling & $34.100,00$ & Sangat Padat \\
\hline 3 & Tambaksari & $33.198,41$ & Sangat Padat \\
\hline 4 & Rangkah & $26.334,29$ & Sangat Padat \\
\hline 5 & Ploso & 23.987,92 & Sangat Padat \\
\hline 6 & Kapas Madya Baru & $26.030,38$ & Sangat Padat \\
\hline 7 & Pacarkembang & $19.651,67$ & Sangat Padat \\
\hline 8 & Gading & $38.564,56$ & Sangat Padat \\
\hline \multicolumn{4}{|c|}{ Kecamatan Gubeng } \\
\hline 1 & Baratajaya & $22.118,42$ & Sangat Padat \\
\hline 2 & Gubeng & $9.183,33$ & Sangat Padat \\
\hline 3 & Mojo & $25.925,57$ & Sangat Padat \\
\hline 4 & Kertajaya & $20.057,69$ & Sangat Padat \\
\hline 5 & Pucang Sewu & $15.957,45$ & Sangat Padat \\
\hline 6 & Airlangga & $13.054,32$ & Sangat Padat \\
\hline \multicolumn{4}{|c|}{ Kecamatan Rungkut } \\
\hline 1 & Kalirungkut & $8.813,18$ & Sangat Padat \\
\hline 2 & Penjaringansari & $10.345,86$ & Sangat Padat \\
\hline 3 & Rungkut Kidul & $10.524,82$ & Sangat Padat \\
\hline 4 & Kedung Baruk & $11.136,77$ & Sangat Padat \\
\hline 5 & Medokan Ayu & $3.370,68$ & Padat \\
\hline 6 & Wonorejo & $2.424,07$ & Sedang \\
\hline \multicolumn{4}{|c|}{ Kecamatan Tenggilis Mejoyo } \\
\hline 1 & Tenggilis Mejoyo & $12.219,15$ & Sangat Padat \\
\hline 2 & Kutisari & $10.925,51$ & Sangat Padat \\
\hline 3 & Panjang Jiwo & $11.063,24$ & Sangat Padat \\
\hline 4 & Kendangsari & $12.831,30$ & Sangat Padat \\
\hline \multicolumn{4}{|c|}{ Kecamatan Gunung Anyar } \\
\hline 1 & Gunung Anyar & $7.155,10$ & Sangat Padat \\
\hline 2 & Gunung Anyar Tambak & $2.013,38$ & Sedang \\
\hline 3 & Rungkut Menanggal & $16.852,17$ & Sangat Padat \\
\hline 4 & Rungkut Tengah & $14.213,98$ & Sangat Padat \\
\hline \multicolumn{4}{|c|}{ Kecamatan Sukolilo } \\
\hline 1 & Keputih & $1.213,47$ & Jarang \\
\hline 2 & Gebang Putih & $5.873,68$ & Sangat Padat \\
\hline 3 & Nginden Jangkungan & $13.930,70$ & Sangat Padat \\
\hline 4 & Semolowaru & $12.053,29$ & Sangat Padat \\
\hline 5 & Medokan Semampir & $10.214,44$ & Sangat Padat \\
\hline 6 & Klampis Ngasem & $11.851,19$ & Sangat Padat \\
\hline 7 & Menur Pumpungan & $10.765,61$ & Sangat Padat \\
\hline \multicolumn{4}{|c|}{ Kecamatan Mulyorejo } \\
\hline 1 & Kejawan Putih Tambak & $3.153,39$ & Padat \\
\hline 2 & Kalisari & $7.095,31$ & Sangat Padat \\
\hline 3 & Kalijudan & $10.268,94$ & Sangat Padat \\
\hline 4 & Mulyorejo & $6.009,30$ & Sangat Padat \\
\hline 5 & Dukuh Sutorejo & $7.697,20$ & Sangat Padat \\
\hline 6 & Manyar Sabrangan & $15.578,76$ & Sangat Padat \\
\hline
\end{tabular}

Kepadatan penduduk di Wilayah Surabaya Timur dominan pada kategori sangat padat mengingat Kota Surabaya merupakan Kota Metropolitan. Sehingga, dilihat dari kepadatan penduduk, wilayah Surabaya Timur memiliki prioritas tinggi untuk RTH. 


\section{B. Penentuan Prioritas Ruang Terbuka Hijau di Wilayah Surabaya Timur}

Penentuan prioritas Ruang Terbuka Hijau dilakukan dengan teknik overlay dengan tools weighted overlay pada ArcGIS dengan input ketiga variabel yang menjadi faktor penentu prioritas RTH yaitu Indeks Kenyamanan THI, Kerapatan Vegetasi NDVI, dan Kepadatan Penduduk. Analisa ini akan menghasilkan sebaran 5 klasifikasi prioritas RTH dimana 2 kelas dengan bobot tinggi yang diarahkan sebagai prioritas RTH. Dengan kriteria skor overlay sesuai dengan Tabel 4, diperoleh prioritas RTH sebagai berikut.

Tabel 8.

Klasifikasi dan Skor Prioritas RTH di Wilayah Surabaya Timur

\begin{tabular}{|c|c|c|c|}
\hline $\begin{array}{c}\text { Skor } \\
\text { Prioritas }\end{array}$ & Keterangan & $\begin{array}{l}\text { Luas } \\
\text { (Ha) }\end{array}$ & $\begin{array}{c}\text { Prosentase } \\
(\%)\end{array}$ \\
\hline 1 & Non Prioritas & 303,88 & 3,12 \\
\hline 2 & Non Prioritas & 598,27 & 6,14 \\
\hline 3 & Non Prioritas & $1.581,75$ & 16,22 \\
\hline 4 & $\begin{array}{l}\text { Prioritas Kedua (Moderate } \\
\text { Priority) }\end{array}$ & $2.851,00$ & 29,24 \\
\hline \multirow[t]{2}{*}{5} & $\begin{array}{l}\text { Prioritas Pertama (High } \\
\text { Priority) }\end{array}$ & $4.414,02$ & 45,28 \\
\hline & Total Luas & $9.746,55$ & 100 \\
\hline
\end{tabular}

Secara keseluruhan, wilayah Surabaya Timur memiliki tingkat prioritas yang tinggi terhadap adanya RTH. Hal ini disebabkan 45,28\% wilayah berada pada prioritas pertama (High Priority). Faktor ketidaknyamanan, kurang vegetasi, dan penduduk yang sangat padat menjadi penyebab dibutuhkannya RTH di kawasan tersebut. Prioritas kedua untuk dikembangkan RTH sebesar 29,24\% wilayah di Surabaya Timur didukung dengan kondisi ketidaknyamanan, vegetasi jarang, dan penduduk padat.

Hasil prioritas RTH diidentifikasi dengan penggunaan lahan sehingga menghasilkan arahan. Oleh karena itu digunakan tools overlay intersect dari ArcGIS. Proses ini akan menghasilkan peta gabungan antara penggunaan lahan dan area prioritas. Berikut tabulasi luasan penggunaan lahan yang memiliki tingkat prioritas RTH.

Tabel 9.

Klasifikasi Prioritas Pertama RTH di Wilayah Surabaya Timur

\begin{tabular}{lrc}
\hline \hline Keterangan & Luas (Ha) & Prosentase (\%) \\
\hline Terbangun & $3.333,93$ & 34,20 \\
Jalan & 816,91 & 8,38 \\
RTH & 124,59 & 1,28 \\
Tambak & 67,31 & 0,69 \\
Tanah Kosong & 0,77 & 0,01 \\
\hline \hline
\end{tabular}

Pada kelas prioritas pertama (high priority) sebesar 34,20\% dari wilayah Surabaya Timur merupakan lahan terbangun dengan prioritas pertama pengembangan RTH. Area jalan sebesar 8,38\%, RTH sebesar 1,28\% dan lahan non terbangunnya yaitu tambak 0,69\%, tanah kosong 0,01\%, dan pertanian $0,19 \%$.

Tabel 10.

Klasifikasi Prioritas Kedua RTH di Wilayah Surabaya Timur

\begin{tabular}{lrc}
\hline \hline Keterangan & Luas (Ha) & Prosentase (\%) \\
\hline Terbangun & $1.410,33$ & 14,47 \\
Jalan & 371,31 & 3,81 \\
RTH & 305,09 & 3,13 \\
Tambak & 595,91 & 6,11 \\
Tanah Kosong & 1,36 & 0,01 \\
\hline \hline
\end{tabular}

Pada kelas prioritas kedua (moderate priority) sebesar 14,47\% wilayah Surabaya Timur merupakan lahan terbangun dengan prioritas kedua pengembangan RTH. Area jalan sebesar 3,81\%, RTH sebesar 3,13\% dan lahan non terbangunnya yaitu tambak 6,11\%, tanah kosong 0,01\%, dan pertanian $1,14 \%$.
Prioritas RTH menghasilkan arahan yang berbeda-beda tiap penggunaan lahan. Berikut total dari prioritas RTH berdasarkan penggunaan lahannya.

$$
\text { Tabel } 11 .
$$

Prioritas RTH di Wilayah Surabaya Timur

\begin{tabular}{crc}
\hline \hline Keterangan & Luas (Ha) & Prosentase (\%) \\
\hline Terbangun & $4.744,26$ & 48,66 \\
Jalan & $1.188,22$ & 12,19 \\
RTH & 429,67 & 4,41 \\
Tambak & 663,23 & 6,80 \\
Tanah Kosong & 2,14 & 0,02 \\
\hline
\end{tabular}

Berdasarkan penentuan prioritas RTH di Wilayah Surabaya Timur, 48,66\% atau 4.744,26 Ha kawasan terbangun yang terdiri dari fasilitas umum, industri dan pergudangan, militer, perdagangan dan jasa, serta permukiman perlu dilakukan upaya penghijauan untuk menurunkan fenomena Urban Heat Island yang terjadi.

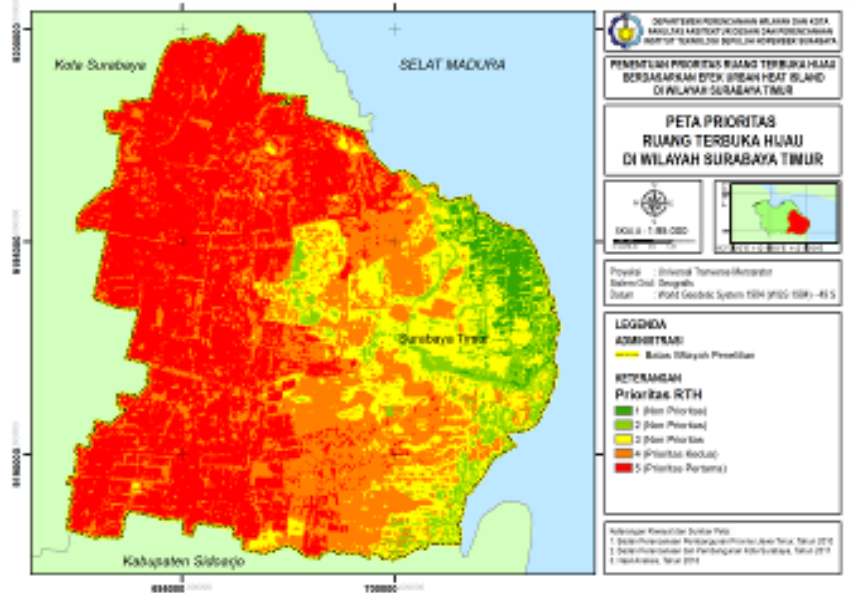

Gambar 3. Peta Prioritas RTH di Wilayah Surabaya Timur

Upaya yang dapat dilakukan adalah pengembangan roof garden pada bagian atap bangunan yang ditanami dengan tanaman yang tidak terlalu besar dan berat agar tidak merusak bagian atap bangunan[10]. Konsep green building yang saat ini mulai digunakan juga perlu dikembangkan di Wilayah Surabaya Timur agar dapat memperbaiki iklim di sekitar kawasan terbangun.

Prioritas RTH di area jalan sebesar 12,19\% atau 1.188,22 Ha menunjukkan perlunya upaya penghijauan di area jalan sebagai sumber dari polusi udara akibat aktivitas transportasi. Perlunya sistem jalur hijau/sabuk hijau di area jalan dan pinggir jalan dengan jenis tanaman yang memiliki nilai estetis dan cukup rindang[10].

RTH eksisting di Wilayah Surabaya Timur yang perlu adanya peningkatan kualitas karena termasuk dalam prioritas RTH yaitu sebesar 4,41\% Wilayah Surabaya Timur atau 429,67 Ha. RTH eksisting tersebut perlu dilakukan penghijauan dengan meningkatkan tanaman yang fungsinya seperti hutan kota sebagai penghasil oksigen, penyerap karbondioksida, peresap air, penahan angin dan peredam kebisingan, berupa jenis komposisi tanaman pepohonan yang tinggi dikombinasikan dengan tanaman perdu dan rerumputan.

Lahan non terbangun yang diprioritaskan sebagai RTH menjadi penekanan untuk arahan penambahan RTH. Terdapat 794,67 Ha terdiri dari 663,23 Ha Tambak, 2,14 Ha Tanah Kosong, dan 129,30 Ha Pertanian yang perlu dialihfungsikan menjadi RTH karena termasuk dalam prioritas RTH. Dari penelitian ini, lahan non terbangun yang termasuk dalam prioritas RTH diubah menjadi RTH yang memiliki fungsi ekologis terutama menurunkan suhu sebagai dampak dari fenomena Urban Heat Island. Upaya 
penambahan RTH dari lahan non terbangun ini akan meningkatkan prosentase RTH Eksisting yang awalnya 8,03\% (783,06 Ha) ditambahkan dengan arahan prioritas RTH 794,67 Ha sehingga total RTH menjadi 16,18\% (1.577,73 Ha).

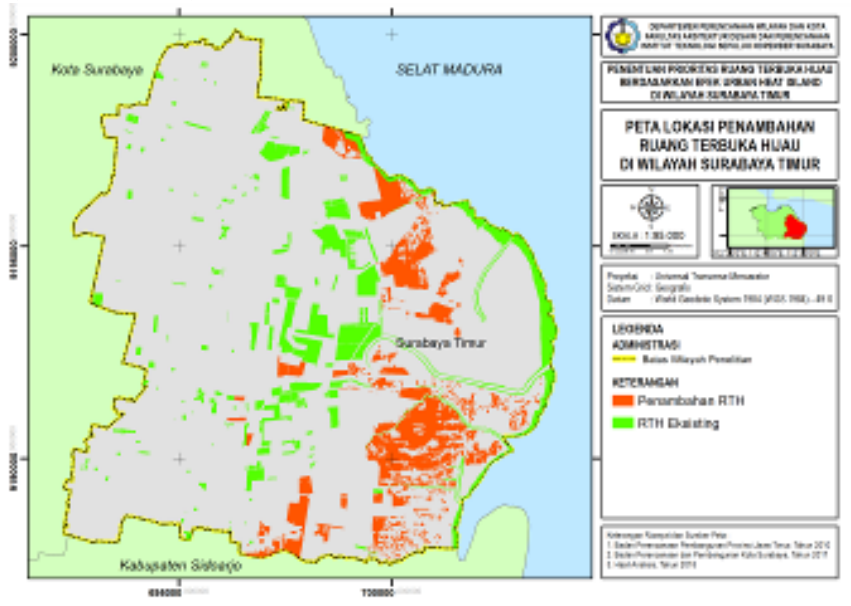

Gambar 4. Peta Sebaran Lokasi Penambahan RTH di Wilayah Surabaya Timur

\section{KESIMPULAN}

Faktor-faktor yang menentukan Prioritas Ruang Terbuka Hijau di Wilayah Surabaya Timur ditunjukkan dengan aspek biologis yaitu nilai kerapatan vegetasi NDVI, aspek fisik yaitu indeks kenyamanan THI, dan aspek sosial yaitu kepadatan penduduk. Indeks vegetasi NDVI menghasilkan angka -0,6156 hingga 0,8029. Klasifikasi non vegetasi $5,32 \%$, kerapatan sangat jarang 29,44\%, kerapatan jarang $37,35 \%$, kerapatan sedang $17,77 \%$, kerapatan padat 7,91\%, dan kerapatan sangat padat 2,22\%. Indeks kenyamanan THI diperoleh dari kalkulasi anatara suhu permukaan (LST) dengan kelembaban relatif $(\mathrm{RH})$. Suhu Permukaan menunjukkan rentang $23,7352^{\circ} \mathrm{C}$ hingga $36,4061^{\circ} \mathrm{C}$ sedangkan kelembaban relatif sebesar 69,4650\% hingga 73,1528\%. Kalkulasi THI menunjukkan rentang 22,4045 hingga 34,3248, meliputi 8,6\% kategori nyaman, 17,1\% kategori kurang nyaman, dan 74,3\% kategori tidak nyaman. Kepadatan penduduk di tiap kelurahan di Wilayah Surabaya Timur dominan memiliki kepadatan penduduk sangat padat $\left(>5.000 \mathrm{jiwa} / \mathrm{Km}^{2}\right)$.
Penentuan Prioritas Ruang Terbuka Hijau melalui teknik overlay dari 3 faktor penentu dari aspek biologis, fisik, dan sosial. Prioritas RTH ditentukan dari skor overlay 4 (Moderate Priority) dan 5 (High Priority). Hasil prioritas RTH menunjukkan perlu adanya penghijauan dengan konsep green building di area terbangun sebesar 4.744,26 Ha, penerapan jalur hijau pada area jalan sebesar 1.188,22 Ha, dan penghijauan RTH sebesar 429,67 Ha. Sedangkan untuk penambahan RTH dari RTH eksisting dilakukan pada 663,23 Ha tambak, 2,14 Ha tanah kosong, dan 129,30 Ha lahan pertanian. Arahan penambahan RTH dari prioritas RTH meningkatkan luasan RTH eksisting 783,06 Ha menjadi 1.577,73 Ha atau 16,18\% dari total Wilayah Surabaya Timur.

\section{DAFTAR PUSTAKA}

[1] L. Tursilowati, "Urban heat island dan kontribusinya pada perubahan iklim dan hubungannya dengan perubahan lahan,” in Prosiding Seminar Nasional Pemanasan Global dan Perubahan Global, 2002.

[2] U.S. Environmental Protection Agencys Office of Atmospheric Programs, "Reducing urban heat islands: Compendium of strategies," 2014.

[3] Kementerian Dalam Negeri RI, Buku induk kode dan data wilayah administrasi pemerintahan per provinsi, kabupaten/kota dan kecamatan seluruh Indonesia. Kementerian Dalam Negeri RI, 2015.

[4] Badan Pusat Statistik Kota Surabaya, Kota Surabaya dalam Angka 2017. Surabaya: Badan Pusat Statistik Kota Surabaya, 2017.

[5] D. B. Sencaki, "Analisa relasi perubahan tutup lahan dan suhu permukaan tanah di Kota Surabaya menggunakan citra satelit multispektral tahun 1994-2012,” Institut Teknologi Sepuluh Nopember, Surabaya, 2014.

[6] N. Humaida, "Metode penentuan prioritas ruang terbuka hijau di Kota Banjarbaru Kalimantan Selatan,” Institut Pertanian Bogor, 2015.

[7] H. Tran, D. Uchihama, S. Ochi, and Y. Yasuoka, "Assessment with satellite data of the urban heat island effects in Asian mega cities," Int. J. Appl. Earth Obs. Geoinf., vol. 8, no. 1, pp. 34-48, Jan. 2006.

[8] B. A. Norton, A. M. Coutts, S. J. Livesley, R. J. Harris, A. M. Hunter and N. S. G. Williams, "Planning for cooler cities: A framework to prioritise green infrastructure to mitigate high temperatures in urban landscapes,” Landsc. Urban Plan., vol. 134, pp. 127-138, Feb. 2015.

[9] Sugiyono, Metode Penelitian Pendidikan: Pendekatan Kuantitatif, Kualitatif dan R\&D. Bandung: Alfabeta, 2006.

[10] M. Fajar, "Pengembangan ruang terbuka hijau berdasarkan distribusi suhu permukaan dan Temperature Humidity Index (THI) Kota Palembang,” Institut Pertanian Bogor, 2010. 